\title{
A Survey of Science Teachers' Perception and Practices in Inclusive Science Classrooms
}

\author{
Tang Wee Teo \\ National Institute of Education, Nanyang Technological University, \\ 1 Nanyang Walk, Singapore 637616 \\ tangwee.teo@nie.edu.sg \\ Received: 12 July 2020 | Revised: 31 October 2020 | \\ Accepted: 19 November $202 \mathrm{O}$
}

\begin{abstract}
This paper reports on a first study about Singapore primary science teachers' views and practices in inclusive science classrooms. Rasch analysis was performed on an online teacher survey administered to 108 teachers, which was conducted to investigate teachers' views about students with special education needs (sEN; Construct A), self-efficacy views in teaching students with SEN (Construct B), and their science teaching practices in inclusive classrooms (Construct $\mathrm{C}$ ). The findings show that it was generally easy for the science teachers to agree with items in Constructs B and C, but not in Construct A. A closer examination of the individual constructs revealed positive teachers' views, their feelings of inadequacy and wish for greater school support, and selected types of accommodations and modifications practiced in their classrooms. This study contributes new insights drawn from an Asian study, offers a validated instrument, and provides science teacher educators ideas for supporting science teachers in inclusive science teaching.
\end{abstract}

\section{Keywords}

Singapore science teachers - inclusive - special education needs 


\section{Introduction}

This article contributes to conversations about education equity in the context of science education from the perspectives and practices of science teachers in the inclusive education system of Singapore. It is through the science teachers and their teaching that students gain access to fair and inclusive systems the two components of equity (Organisation for Economic Co-operation and Development, 2008). However, as advocacy for the inclusion of students with special education needs (SEN) in mainstream classrooms has become more globally widespread, teachers are being confronted with the challenge to teach in increasingly diverse classrooms comprising a range of student learning needs including dyslexia, autism spectrum disorders, and attention deficiency.

The term "special education needs" carries different meanings in different studies and contexts. It can refer to physical disabilities, learning difficulties, and socio-economic disadvantages. In this paper, I use the term "special education needs" broadly to include physical, emotional, behavioral, cognitive, and other conditions that hinder students from learning. I prefer this term over the term "disability" (which carries a deficit undertone) and the term "difficulty" (which downplays the severity of intrinsic challenges students with SEN confront). The term "disadvantage" has strong connections to systemic and institutionalized structures that, although they may hinder students' academic performance, do not reside within individuals (Herrick, 1973).

The learning difficulties of students with SEN can hinder their learning of core concepts needed to make sense of more abstract scientific concepts and develop new knowledge (Mastropieri \& Scruggs, 1992). In comparison to the existing general SEN literature, studies about SEN issues and topics in disciplinary-specific domains are sparse. This phenomenon seems to suggest that challenges in subject-based classroom teaching and learning can be understood by drawing upon the general SEN literature. While there may be some "truth" (albeit limited) to this view, I raise questions about science teachers' views and teaching practices, specifically in inclusive classrooms. Depending on the relational positionality (Teo, 2015) of teachers, they interact with students differently as subject- and non-subject-based teachers. Case studies by Teo (2015) illuminated how science teachers' views and actions change inside and outside of the physical science classroom boundary. In that study, the two science teachers showed greater empathy for their marginalized students, offered additional tutoring to students, and provided emotional support. However, they undertook a different stance in the science classrooms as they expected all their students to meet expectations regardless of personal 
circumstances, socioeconomic status, race, and gender. The physical space of the science classroom became a symbolic boundary that demarcated the two science teachers' binary views and efforts. Drawing upon this example, I wonder how would situating teachers within an inclusive science classroom mediate their views about their students with SEN, their self-efficacy views as science teachers, and their teaching practices?

According to a review by Azman and Teo (2019), the majority of the empirical studies about SEN were conducted in North America, and the research participants were students. However, as mentioned earlier, the term "special education needs" in diverse contexts may be understood differently. For example, gifted children and students with learning disabilities may be collectively referred to as having SEN in some countries. However, in Singapore, SEN does not included children who are gifted. Additionally, inclusion could mean mainstreaming in terms of having students with SEN in the same classes for the entire or partial school day. In Singapore mainstream schools, students with SEN are in the same classes with the other students for all lessons.

The study was conducted in Singapore and forms part of a larger study examining the perceptions of primary science teachers and actual practices in the science classrooms with students with SEN. Below, I provide more background information about the special needs education policy and science teacher education in SEN in Singapore.

\subsection{Special Needs Education Policy in Singapore}

According to the Achieving Inclusion in Education (Disabled People's Association [DPA], 2016)

Inclusive education is based on the premise that all individuals with disabilities have a right to education, without discrimination or exclusion. It is an educational approach and philosophy that looks into how education systems can be modified or improved to respond to the diversity of learner. (p. 35)

In order for the goal of inclusive education to be achieved, such a system requires the provision of accessible environments, appropriate teaching aids and equipment, child-centered curriculum, flexible teaching methods, family 
and community involvement, quality teaching training, and well-supported teachers (DAP, 2016).

Globally, the number of children diagnosed with developmental issues has increased over the years. In Singapore, the number of diagnosed cases increased from 2,500 to 4,400 from 2010 to 2014 , registering a $76 \%$ increase (Ministry of Social and Family Development, 2016). The number of children diagnosed with autism spectrum disorder is 1 in 150 children (as compared to the 1 in 160 world average according to the World Health Organization). The Singapore government has expressed its commitment to inclusive education in several documents and policies, including the five-year roadmaps articulated in the First Enabling Masterplan 2007-2011, Second Enabling Masterplan 2012-2016, and Third Enabling Masterplan 2017-2021 (National Council of Social Service, 202O). To highlight a few key policies related to SEN, the amendments to the Compulsory Education Act (2019) have included children with moderate to severe SEN. With this amendment in place, it is compulsory for children of primary school age with mild SEN who have the cognitive abilities and adequate adaptive skills to be schooled. Children with moderate to severe SEN will attend government-funded special education (SPED) schools. Initiatives that have been put in place to support students with various disabilities in mainstream school, include having at least one allied educator (AED) providing learning and behavioral support (LBS) in every primary school, preservice teacher training on special needs (a compulsory 12-hour module on special needs for all beginning teachers since 2005), and other school-based intervention programs (a complete list can be found in the Disabled People's Association's (2016) guide, Achieving Inclusion in Education). In 2020, the SkillsFuture for Educators (SFEd) framework, which identifies the six prioritized areas of practice for Singapore educators, was rolled out. These six areas include assessment literacy, differentiated instruction, inquiry-based learning, e-pedagogy, civic and character education, and support for students with SEN. Specifically, for the last area of practice, teachers will focus on enhancing their practice to implement effective strategies for supporting students with SEN (MOE, 202O).

\subsection{Science Teacher Education in SEN in Singapore}

Almost all science teachers teaching in public, autonomous, and independent schools in Singapore have undergone the postgraduate diploma in education (primary/secondary/junior college) or bachelor of science (Education) program at the National Institute of Education. While topics such as teaching science to students with diverse needs and differentiated science instruction 
are discussed in some lessons, none of the science education courses has yet focused on teaching students with SEN. A scan of the other science teacher education programs on websites show a similar situation in most science teacher education programs around the world. There are several possible reasons to explain this. For example, teacher education programs tend to be short and many other more commonplace topics (e.g., constructing science assessments, science pedagogies, lesson plan writing, and microteaching) have to be completed.

However, the gap in the SEN training of science teachers has been addressed through continual teacher professional development. For example, the NIE Professional Learning Catalogue for January to June 2020 (NIE, 2O2O) shows that there was a Certificate in Special Needs Support program that "serves to provide mainstream teachers in the primary and secondary schools with more in-depth knowledge, skills and understanding of the special needs of diverse learners and foster the development of teachers' education" (p. 4). Additionally, there was a Certificate in Teaching Students with Autism in Special Education School that "focus[es] on enhancing the capacities, skills and practices of the teachers teaching students with autism" (p. 5). Other certification programs include the Advanced Diploma in Special Learning and Behavioral Needs and the Advanced Diploma in Special Education. Other non-certification professional development courses related to SEN include the Assessment for Students with Special Educational Needs - Basic Level and Teaching Primary Science in Inclusive Classrooms.

\section{3}

\section{Research Questions}

This paper contributes to the existing SEN literature by offering insights based upon a baseline scan of Singapore primary (Grades 3-6, ages 10-12) science teachers' self-reported views and teaching practices in inclusive classrooms.

The research questions that I address in this study are:

1. What are Singapore primary school science teachers' views about their students with SEN?

2. What are Singapore primary school science teachers' views about their self-efficacy in teaching students with SEN in inclusive classrooms?

3. What are Singapore primary science teachers' science teaching practices in inclusive science classrooms?

The study focused on primary schools as aligned to advocacy for early intervention for students with SEN (Mitchell \& Brown, 1991). Rasch modeling for 
measuring latent variables (Boone, 2016; Bond, 2015) was applied to the science teachers' views about students with SEN, their self-efficacy views in teaching students with SEN, and their science teaching practices in inclusive classrooms. The findings of this study could inform the design of science teacher education programs to address specific issues or gaps in the current state of science teacher preparation for teaching in inclusive classrooms. Separately, this study also yielded a validated instrument that could be used to (1) conduct comparative studies that identify future and international research agenda and (2) identify strategies to promote greater efforts in science teacher preparation for inclusive science teaching.

\section{Literature about Science Teachers in Inclusive Classrooms}

In a literature search conducted by Azmin and Teo (2019) on EBSCOhost, Taylor and Francis, SAGE, Wiley, and ScienceDirect search engines, 49 articles related to teachers of inclusive science classrooms were found. Among these articles, 38 articles (78\%) studied in-service teachers, nine articles (18\%) studied preservice teachers, and two articles (4\%) studied both groups of teachers. Many papers reported studies that examined variables related to teacher attitudes, perceptions, and practices toward inclusive education. Among the 49 articles, 37 different perceptions were identified. These could be re-grouped into five broad categories: school related (e.g., support and resources available), student related (e.g., severity of learning needs), society related (e.g., society or culture), teacher demographic factors (e.g., years of teaching and gender), and changeable teacher factors (e.g., training in SEN and exposure to students with SEN). Only one paper $(2 \%)$ explored teachers' views on ways to optimize the potential of students with SEN in inclusive classrooms.

The findings of the literature review were informative in the identification of the three theoretical constructs in the teacher survey implemented in this study. First, it was interesting to note that there was a relatively small amount of empirical research in science education that focused on teachers and teaching. This suggested the need to build on the existing work to gain a better understanding about how and what science teachers were thinking and doing in inclusive science classrooms. Second, the review showed that the target research participants were in-service teachers and not pre-service teachers. This could be because in-service teachers had greater experience and contacts with students with SEN through their years of teaching and would therefore be able to better express their views with regard to teaching students with SEN. 
The different perceptions identified from the articles were integrated into the construction of the survey items - organized into three constructs - reported in this paper.

Teachers' attitudes, their knowledge about SEN, and teaching strategies had been identified as prerequisites for implementing inclusive education successfully (Kurniawati, DeBoer, Minnaert, \& Mangunsong, 2016). The strong connection between perception and actions (e.g., Brady \& Woolfson, 2008; Wang et al., 2011) has been well established. This knowledge was underpinned by the theory of planned behavior (Ajzen, 1991) that posited the centrality of intention. The intentions encapsulated the motivational factors that influenced behaviors. Intentions were also proxy indicators of how hard individuals would try and how willing they would be to exert effort to perform the behavior. There was a direct relationship between intentions and performed behavior. On the other hand, the individuals' attitude toward the behavior, subjective norms (social factor), and perceived behavioral control (ability) were three factors that affected one another and also influenced the intentions. The perceived behavioral control might also directly affect the engaged behavior. For example, imagine that a science teacher read about the types of modifications that they could make for students with SEN during assessments. However, their head of department told them that it was not a practice in the department to offer modified assessments for students with SEN because other students might perceive it as being unfair. The teacher thought that it was not within their power to make change and hence gave up on the idea to make assessment modifications. During the test, she gave the same unmodified test paper to all her students. In this case, the subjective norm (i.e., views of fairness) was a key factor in determining the engaged behavior.

In this study, the first two constructs (A and B) could shape the science teachers' attitude toward the behavior (Construct $\mathrm{C}$ ). While all three constructs could be theoretically connected, the focus of the study was to obtain an in-depth understanding of each construct and not the connections between them. Accordingly, I discuss each of the constructs.

\subsection{Teachers' Views about Students with SEN}

Teachers' views about students can shape their attitudes that, in turn, affect their behaviors and actions (Fishbein \& Ajzen, 1975; Van Reusen, Shoho, \& Barker, 2001). Many existing studies about SEN have examined teachers' views about education inclusion. However, it is not examined in this paper, as engaging in a debate over the education policy on inclusion was not a purpose of this study. From a more practical standpoint, this study focused on the science 
teachers' views about their students with SEN in inclusive science classrooms so that this baseline study of Singapore teachers could inform the design of future teacher education programs.

Existing literature about teachers' views of students with SEN has shown that while most teachers recognized the benefits of education inclusion, their views could be conflicted and deficit in nature. Deficit views included the thinking that students with SEN should not participate in science alongside other students, and that learning difficulties were used as excuses for failure. Some teachers expressed unwillingness to teach students with SEN or preferred that they were not visible (Kahn \& Lewis, 2014; Norman, Caseau, \& Stefanich, 1998). On the other hand, some teachers were receptive to working with students with SEN and were willing to make accommodations and modifications for them (Norman et al., 1998). Teachers might embrace the idea of teaching science in an inclusive setting as they believed in affording students with SEN the opportunity to excel in science. Because they might believe in the ability of students with SEN to excel in science, they were reluctant to give such students a passing grade if their academic performances were below expectations. This illuminated an important point about how similar views could lead to contradicting outcomes, and how views, even if positive, could become a double-edged sword.

\subsection{Self-Efficacy Views in Teaching Students with SEN}

Teachers' self-efficacy views in teaching students with SEN were closely related to teacher preparedness to teach them. Their level of preparedness was in turn, affected by how much teaching training they had received (Kahn \& Lewis, 2014). Several studies (Kahn \& Lewis, 2014; Norman et al., 1998; Rojewski \& Pollard, 1993) have reported that teachers felt unprepared to teach students with SEN. According to them, they had received little or no formal training in teaching students with SEN in their pre-service and in-service teacher education programs and courses. In cases where topics on SEN were taught, the instruction was introduced in a general education course (rather than discipline-specific education course, e.g., science education), the discussion was brief with only superficial coverage and no further reinforcement, and the course was an elective. In discipline-specific education courses, this topic could be sidelined as the instructors assumed that the topic on teaching students with SEN had been covered in the general education courses, and more time was devoted to the teaching of pedagogies for specific subject-specific topics (e.g., alternative conceptions in learning electricity). 
Besides pre-service and in-service teachers, teacher educators themselves were likely to have limited knowledge and skills on teaching children with SEN (Kahn \& Lewis, 2014; Norman et al., 1998). They might have little or no experience teaching in inclusive classrooms as former teachers, and their specialization might not be in the area of special needs education anchored in a discipline. In fact, the paucity of research on SEN in science education research, in comparison to other topics (e.g., alternative conceptions, pedagogies, inquiry, assessment, and so on), indicates a lack of sufficient expertise about SEN among science education researchers. It was thus logical to infer that there were few science education courses with an emphasis on special needs science education.

\subsection{Teaching Practices in Inclusive Science Classrooms}

The concepts of accommodation and modifications (PACER Center, 2013) were key to the adaptation of teaching practices in inclusive science classrooms. An accommodation allowed for a student with SEN to complete the same assignment or test, but with some adjustments to the timing, formatting, setting, scheduling, response, and/or presentation. A modification is an adjustment made to an assignment or a test to change the standard or what they are supposed to measure. In Mastropieri and Scrugg's (1992) review of 66 articles on science for students with SEN, 21 articles reported on adaptations made for learning. Among these articles, 13 of these used mnemonics and eight reported about making text and other adaptations. In a study with 19 students with mild SEN, it was found that mnemonic instructions had resulted in substantial increases in initial science content acquisition and substantially higher delayed-recall scores over more traditional instructional procedures (Scruggs \& Mastropieri, 1991). Further, the students were able to successfully generate and apply their own mnemonic strategies to novel content. They also expressed overwhelming preference for mnemonic strategies as compared to traditional instruction methods. In a randomized field study of 213 Grade 8 students with mild SEN in the U.S., it was found that collaborative hands-on activities facilitated the students' science content learning and they enjoyed the activities (Mastropieri, Scruggs, Norland, Berkeley, McDuffee, Tornquist, \& Connors, 2006). In another study that compared the effectiveness of comprehensionfostering strategies (i.e., text-structure-based, paragraph restatement, or traditional) for 54 Grade 8 studies with SEN, it was found that text structure-based reading strategies had a significant effect on the recall of central and incidental information over traditional instruction on immediate, delayed, and transfer tests. The text structure-based strategy also had significant effect on the recall 
of central, but not incidental, information over the paragraph restatement strategy on immediate, delayed, and transfer tests. In sum, there have been studies that have established the effectiveness of certain teaching strategies in science teaching of students with SEN.

In summary, this section discussed the rationale and significance of this study in addressing the gaps in science education research with a focus on SEN in the Singaporean context, where science teaching and learning is fully inclusive. To set the conversation in context, I discussed the SEN policy in Singapore and the literature related to the three constructs measured in the teacher survey. Accordingly, I explained the research methods.

\section{$5 \quad$ Methods}

\subsection{Research Participants}

The research participants were Singapore science teachers from Grades 3-6 (ages 9-12) in primary schools. One hundred and eight $(29 \%$ male and $71 \%$ female) primary science teachers completed the online survey. About $83 \%$ of the teachers were $26-45$ years of age and $62 \%$ had a bachelor's degree. About $40 \%$ of the teachers had more than 10 years of teaching experience. About $69 \%$ of the teachers had some interaction with students with SEN outside the classroom, and about $57 \%$ of them had undergone 1-10 hours of training in SEN education. On a scale of o (low) to 5 (high), $34 \%$ of the teachers rated 2 as their level of confidence in teaching or supporting students with SEN.

\subsection{Data Collection}

After obtaining the Institutional Research Ethics Clearance and approval from the Ministry of Education to conduct the study, an email was sent to all school principals in mainstream and inclusive primary schools to recruit science teachers for an online survey. In the recruitment email, the following selection criteria for research participants were specified: (a) science teachers from Grades 3-6 (because science was taught in schools only at these grade levels), (b) prior or current experience teaching science in inclusive classrooms, and (c) experience teaching students with SEN such as autism spectrum disorders, attention deficit hyperactivity disorder (ADHD), intellectual disabilities, and/ or learning disabilities (e.g., dyslexia). With the school principals' support of the study, they assisted in the dissemination of the recruitment email containing the anonymous survey weblink and QR code and consent form to the 
teachers. The teachers completed the survey on their own time over a period of about two months. Participation was voluntary and consent was provided by the research participants. One hundred and eight teachers responded to the invitation and completed the online survey.

\subsection{Instrumentation}

The online survey (see Appendix A) was constructed in four main phases (see Figure 1), aligned to the main principles of survey design and validation by Creswell (2008).

The first phase involved the identification of suitable constructs and items for measurement. I began with a literature search conducted on studies that concern teachers and surveys or questionnaires. More than 100 relevant articles were found, and the survey or questionnaire items were consolidated. A review of the literature revealed the constructs and items measured in studies that examined teachers' views about SEN using surveys or questionnaires. I went through all the constructs to identify the ones that were relevant for the study and to rationalize reasons for not including certain constructs in the study. For example, the construct on teachers' views about inclusion was excluded because education inclusion has been and remains a policy in Singapore. While investigating science teachers' views about inclusion might

\section{Phase 1 - Identify suitable constructs}

Literature review on teacher surveys and questionnaires in SEN studies

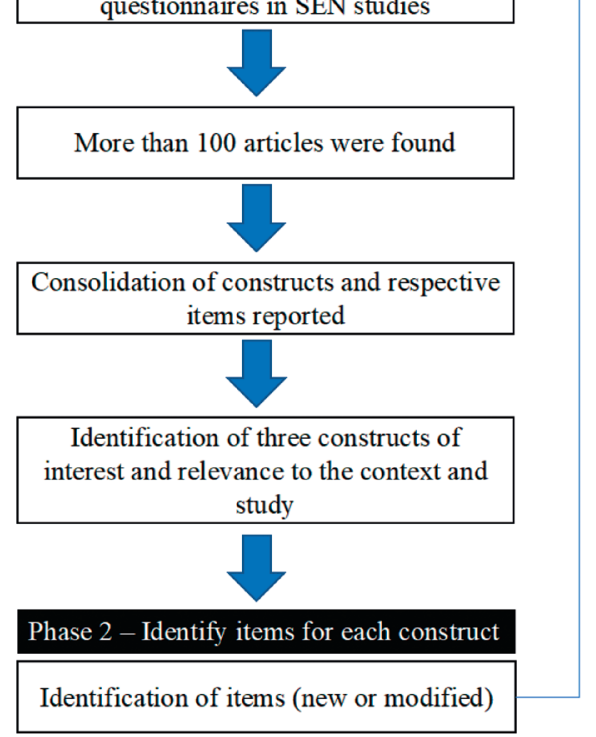

Phase 3 - Qualitative validation

Teacher interviews on the first draft of the survey

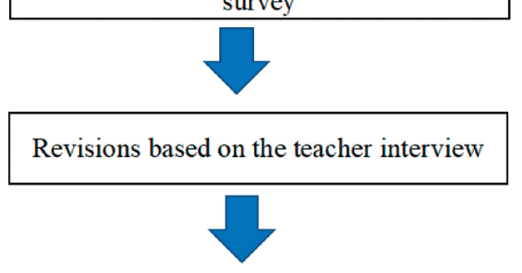

Phase 4 - Finalization of the survey

Feedback from three experts

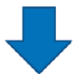

Revisions and finalization of survey

FIGURE 1 Overview of the survey design process 
be important, it would be more useful (given the limited time to survey the teachers and reduce survey fatigue) to find out their self-efficacy views in teaching students with SEN in their science classrooms. Notably, in addition to the five-point Likert-scale items for the three constructs, other demographic items and items that were not specifically related to the constructs were included to give more insights on the findings (see Appendix A).

Following the identification of relevant constructs, in the second phase of the survey design, the items consolidated under each construct were reviewed. The relevant items were selected and modified when necessary to improve on item quality (e.g., clarity, conciseness, and containing a single meaning). The modifications also took into consideration the Singapore teachers who took the survey by ensuring that there was no contextually irrelevant information or unfamiliar terms. This process was important for ensuring (a) construct validity (Salkind, 2010a), so that the survey findings accurately measured the construct of interest to this study, and (b) content validity (Salkind, 2010b), so that the research questions were adequately addressed.

In the third phase of the survey design, qualitative validation of the construct and content were carried out via in-depth interviews with two experienced Singapore primary school teachers. These two teachers had taught in mainstream public primary schools similar in profile to most primary schools in Singapore. Their demographic backgrounds were also similar to the majority of the research participants in this study. Their interpretations and feedback on every item and suggestions on revisions to the items were sought. The items were subsequently modified to improve on their quality.

After revising the items based on the teachers' responses gathered in the third phase, in the final phase the draft survey was shared with one university professor with specialization in SEN, one specialist with expertise in SEN, and one expert teacher who specialized in teaching primary science. Suggestions to include a few other items pertaining to each construct or the general scope of the study were provided. The latter were analyzed separately from the constructs. After they provided their comments and feedback on the survey, the items were revised again before implementation.

The final online survey comprised three constructs (with 10, 15, and 11 items, respectively), demographic items (e.g., educational qualifications and years of teaching experience), and other individual items (see Appendix A). I wish to highlight that the SEN were limited to a few learning needs most commonly reported in the Singapore context. Hence, the following statement was included in the survey to provide the scope for the study: "For this survey, the phrase 'special education needs' (SEN) only includes autism spectrum disorders, ADHD, intellectual disabilities, and learning disabilities (e.g., dyslexia)." 


\subsection{Data Analysis}

The items in three constructs were analyzed and validated using the Rasch model using WINSTEP software, while the other individual items that were not directly related to the constructs were analyzed using descriptive statistics. In order for Rasch modeling to be adopted, each construct should preferably contain at least 10 related items. Hence, for Constructs A-C, there were at least 10 items per construct. The other items that could not be analyzed using Rasch modeling were analyzed descriptively. In essence, the two types of statistical analysis served different purposes and were applied where appropriate.

All the rating scales for the individual constructs were calibrated separately using Rasch analysis (Wright, 1993; Wright \& Masters, 1982; Wright \& Stone, 1979) to obtain the persons' linear measures for each latent variable in logits (Teo, Goh, Khin, \& Yeo, 2018; Teo \& Goh, 2019). Prior to the analysis, reverse coding was done to ensure unidirectionality, in other words, all statements were positively phrased and responses to negatively phrase items were reversed from strongly agree to strongly disagree and so forth. The standard validation process in Rasch was adopted by examining the fit statistics: item and person separation reliabilities, infit and outfit mean squares, discrimination indices, and standardized residuals. Only one item (B8) was found to have an outfit mean square of 2.10. This was corrected by removing one person's data, which brought the item outfit mean square to below 2.o (Wright \& Linacre, 1994). The person and item reliabilities (see Appendix B) for all three constructs were also above 0.50 , meaning that the instrument was sensitive enough to distinguish the different teachers and that there was a good spread of items of difficulty levels (i.e., the items ranged from easy to difficult to agree with). The Wright distribution maps were used to gain insights into the teachers' perceptions on these variables. Being higher in the Wright distribution map meant that it was harder for the teachers to agree with the item (i.e., that they would most likely disagree).

Findings and Discussion

\subsection{Construct A: Science Teachers'Views about Students with SEN}

Figure 2 below shows the Wright map of Construct A. The item mean ("M" on the right side of the ruler) was slightly more than one logit higher than the person mean ("M" on the left side of the ruler). This meant that, in general, it was harder for the teachers to agree with most of the items in this construct. For example, Item A9, "in comparison to their peers, students with SEN are as proactive in science lessons," was relatively the easiest item for most teachers 


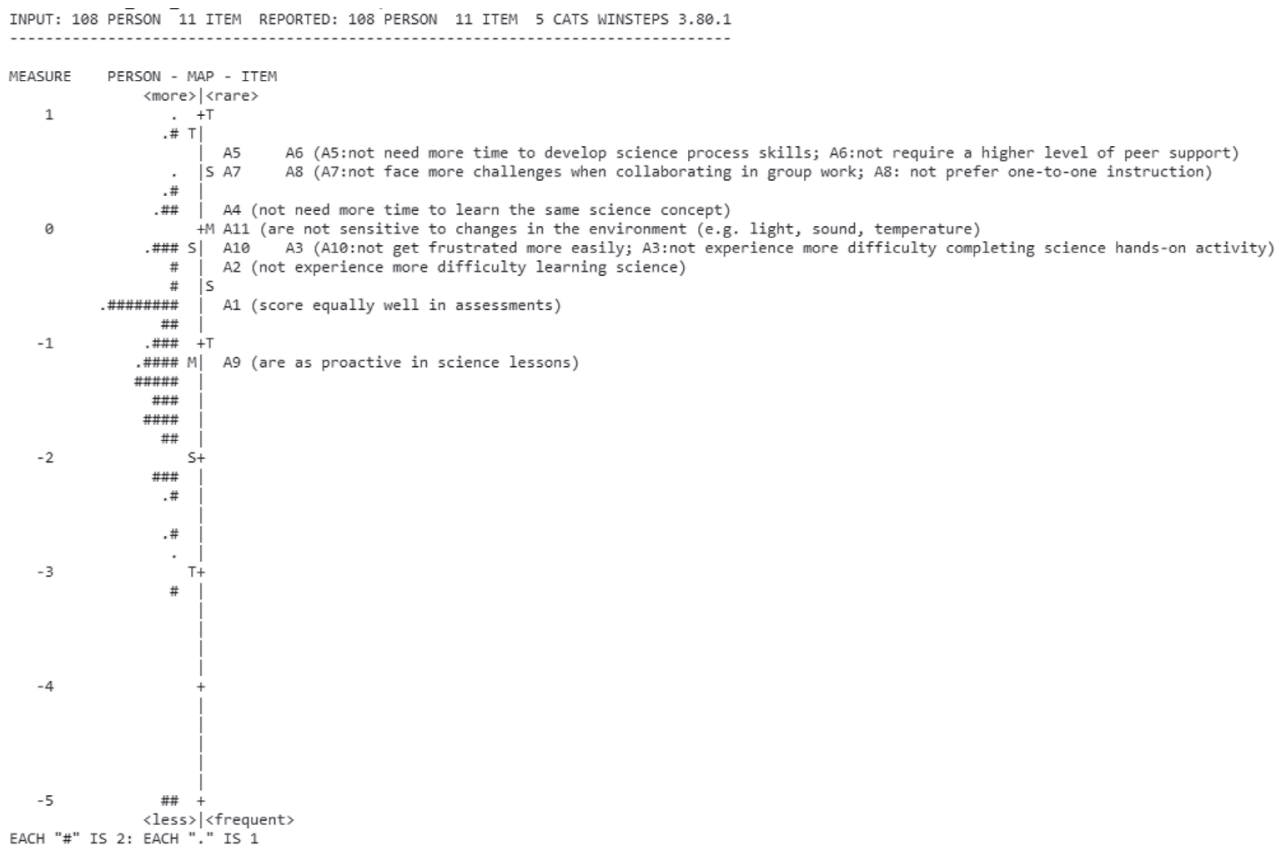

FIGURE 2 Wright map for 'Construct A: Science Teachers Views About Students With SEN'

to agree with. Yet there were 47 teachers $(43 \%)$ who found it difficult to agree with all 11 items in this construct. In what follows, I discuss these views in greater detail.

Among the 11 items, the following were on or above the item mean, meaning that generally the science teachers found it relatively harder to agree with these items:

In comparison to their peers, students with SEN:

A6*: do not require a higher level of peer support

$\mathrm{A}_{5}^{*}$ : do not need more time to develop science process skills

A $8^{*}$ : do not prefer one-to-one instruction

$\mathrm{A}_{7}^{*}$ : do not face more challenges when collaborating in group work

A 4*: do not need more time to learn the same science concept

A11*: are not sensitive to changes in the environment (e.g., light, sound, and temperature)

(“*” reverse coded items prior to Rasch analysis)

The findings show that the science teachers recognized that the students with SEN needed support from peers $\left(\mathrm{A}^{*}\right)$ and preferred stable environmental 
conditions $\left(\mathrm{An}^{*}\right)$. Both of these were conditions found to be beneficial to students with SEN (e.g., Cater \& Kennedy, 2006; Davis \& Florian, 2004; Jimenez, Browder, Spooner, \& Dibiase, 2012; Scruggs \& Mastropieri, 2007). The science teachers' recognition of students' need for one-to-one instruction $\left(\mathrm{A} 8^{*}\right)$ was consistent with their view that collaborative group work might pose challenges to their learning $\left(\mathrm{A}^{*}\right)$. While the social dynamics of the team members had to be managed, structured group work might be academically beneficial for students with SEN (Gillies \& Ashman, 2000).

Science learning involves acquiring knowledge and skills (Hodson, 2014). The science teachers also thought that the students would need more time to develop their science process skills $\left(\mathrm{A}_{5}^{*}\right)$ and to understand science concepts $\left(\mathrm{A}_{4}{ }^{*}\right)$. When both ontological categories (i.e., matter and processes) are invoked, science learning becomes more difficult and conceptual change is harder to achieve (Chi, Clotta, \& Leeuw, 1994). The science teachers were thus probably correct in their views about the students with SEN requiring more time to make meaning and engage with the science content $\left(\mathrm{A}_{4}^{*}\right)$.

Among the 11 items, the following were below the item mean, meaning that generally the science teachers found it relatively easier to agree with these items:

In comparison to their peers, students with SEN:

A10*: do not get frustrated more easily

$\mathrm{A}_{3}$ *: do not experience more difficulty completing science hands-on activity

$\mathrm{A} 2^{*}$ : do not experience more difficulty learning science

A1: score equally well in assessments

$\mathrm{Ag}^{*}$ : are as proactive in science lessons

(“*”" reverse coded items prior to Rasch analysis)

The science teachers possessed positive views about the students' attitudes in science learning. They did not think that students with SEN expressed frustration more easily than other students (A10*). They also thought that students with SEN scored equally well $(\mathrm{Al})$ in assessments and were as proactive in science lessons. Although the science teachers thought that the students would need more time to develop their science process skills $\left(\mathrm{A}_{5}^{*}\right)$, the science teachers did not think that these students experienced more difficulty in completing science hands-on activity $\left(\mathrm{A}_{3}{ }^{*}\right)$ or experienced more difficulty learning science when compared to their peers $\left(\mathrm{A}_{2}^{*}\right)$. In fact, they were as proactive during their science lessons $\left(\mathrm{Ag}^{*}\right)$. 
At the beginning of this section, I highlighted that it was generally not easy for the science teachers to agree on the items in Construct A. However, a closer examination of the items within Construct A revealed positive views of the science teachers toward students with SEN. This finding contrasted with other studies in the literature (e.g., Khan \& Lewis, 2017; Norman, Caseau, \& Stefanich, 1998; Spektor-Levy \& Yifrach, 2019) that have reported science teachers' negative or stereotypical perceptions about these students' ability to meet the sophisticated demands of science instruction, such as problem-solving and inquiry learning (Ellis, 1993; Steele, 2004; Sullivan Palincsar, Magnusson, Collins, \& Cutter, 2001). It is unknown why the science teachers in this study expressed such positive views. However, this could be due to advocacy - in science teacher education courses and in policy speeches by policy makers (e.g., Ong, 2020) - for differentiated instructions to address diverse students' needs. Hence, the science teachers might view a learning difficulty as a differentiated learning need that a student had rather than a need linked to a diagnosis.

\subsection{Construct B: Science Teachers Self-Efficacy Views in Teaching Students with SEN}

There were positive links between teachers' self-efficacy with students' academic adjustments, patterns of teacher behavior and practices related to classroom quality, and factors underlying their psychological well-being (e.g., job satisfaction, commitment, personal accomplishment; Zee \& Kooman, 2016). Figure 3 below shows the Wright map of Construct B. The item mean ("M" on the right side of the ruler) was slightly more than one logit lower than the person mean ("M" on the left side of the ruler). This meant that in general, it was easier for the teachers to agree with most of the items in this construct. For example, Item By, "during my science lessons, I did not avoid making eye contact with students with SEN," was relatively the easiest item for the teachers to agree with. In fact, none of the science teachers found it difficult to agree with this item. The science teachers' positive self-efficacy views were important to their overall perceptions and attitudes toward inclusive science teaching (Urton, Wilbert, \& Hennemann, 2014; Wigle \& Wilcox, 1996). These have impact on how they implemented instructional strategies and methods (Brady \& Woolfson 2008) and, in turn, affected the attitudes of students toward learning and their self-efficacy views (Jarvis \& Pell 2004; Weinburgh 2007). In what follows, I discuss in greater detail the science teachers' self-efficacy views in teaching students with SEN.

Among the 10 items, the following were on or above the item mean, meaning that the science teachers found it relatively harder to agree with these items: 


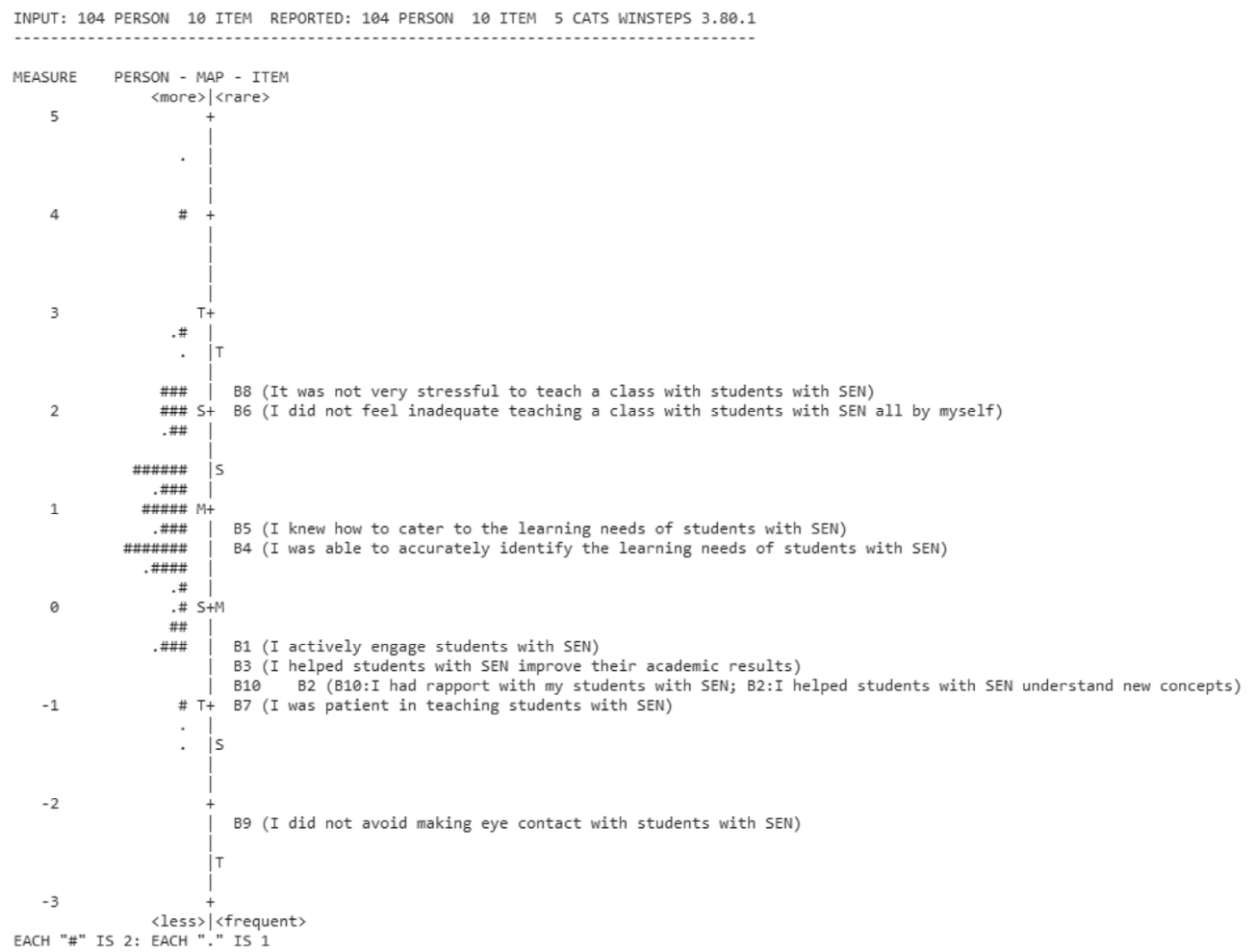

FIGURE 3 Wright map for 'Construct B: Science Teachers Self-Efficacy Views in Teaching Students With SEN'

During my science lessons,

B8*: it was not very stressful to teach a class with students with SEN B6*: I did not feel inadequate teaching a class with students with SEN all by myself

B5: I knew how to cater to the learning needs of students with SEN

B4: I was able to accurately identify the learning needs of students with SEN

(“*” reverse coded items prior to Rasch analysis)

The findings illuminated the support that the science teachers need in order to teach in inclusive classrooms. They expressed feeling stress (B8*) and inadequacy $\left(\mathrm{B}^{*}\right)$ without other teachers to support their lessons. Such feelings were probably compounded by the fact that they did not know how to accurately identify the learning needs of students with SEN (B4) and were therefore 
unable to cater to their learning needs $\left(\mathrm{B}_{5}\right)$. This set of findings was consistent with the data from an item in the online survey that asked them to rate themselves on a scale of o to 5 (highest) on their confidence level in teaching or supporting students with SEN. The mean score was 2.09 (S.D. 1.08), showing generally low confidence levels. Table 1 below shows the results of items related to the support available to the science teachers. The findings showed that while $52.4 \%$ of the science teachers received school support, $45.2 \%$ of them thought that they needed more in order to teach students with SEN. However, $41.7 \%$ of them neither agreed nor disagreed that they needed to undergo professional development in the science teaching of students with SEN. About $33.7 \%$ of the teachers somewhat disagreed that they were ready to teach during their preservice teacher education.

TABLE 1 Teachers' responses on survey items related to support and professional development

Survey item

$\begin{array}{lllll}\begin{array}{l}\text { Strongly } \\ \text { agree }\end{array} \text { agree } & \begin{array}{l}\text { Neither } \\ \text { agree or } \\ \text { disagree }\end{array} & \begin{array}{l}\text { Somewhat Strongly } \\ \text { disagree }\end{array} & \\ & & & \end{array}$

1 I was supported by

$\begin{array}{lllll}9 \cdot 7 \% & 52.4 \% & 21.4 \% & 10.7 \% & 5.8 \% \\ (\mathrm{n}=10) & (\mathrm{n}=54) & (\mathrm{n}=22) & (\mathrm{n}=11) & (\mathrm{n}=6)\end{array}$

my school to teach

students with SEN

$(N=103)$

2 I needed more support

from my school in order

$28.8 \% \quad 45.2 \%$

$19.2 \%$

$6.7 \%$

$0.0 \%$

to teach students with

$(n=30) \quad(n=47)$

$(\mathrm{n}=20) \quad(\mathrm{n}=7)$

$(\mathrm{n}=\mathrm{o})$

SEN $(N=104)$

3 I am well-prepared to

$\begin{array}{lllll}\mathrm{O} . \mathrm{O} \% & 18.8 \% & 21.8 \% & 33 \cdot 7 \% & 25.7 \% \\ (\mathrm{n}=\mathrm{o}) & (\mathrm{n}=19) & (\mathrm{n}=22) & (\mathrm{n}=34) & (\mathrm{n}=26)\end{array}$

teach students with

SEN since I was a

preservice teacher

$(N=101)$

4 I need to undergo

$\begin{array}{lllll}38.2 \% & 0.0 \% & 47.1 \% & 12.7 \% & 2.0 \% \\ (\mathrm{n}=39) & (\mathrm{n}=0) & (\mathrm{n}=48) & (\mathrm{n}=13) & (\mathrm{n}=2)\end{array}$

more professional

development in the sci-

ence teaching of

students with SEN

$(N=102)$ 
Malinen, Savolainen, Engelbrecht, Xu, Nel, Nel, and Tlale (2013), who studied teachers' self-efficacy in inclusive practices in China, Finland, and South Africa, found that teachers' experience in teaching students with SEN was the strongest predictor of self-efficacy across all three countries. In my study, $36 \%$ of science teachers reported having at least one student with SEN in their class, but the student(s) did not require much support. The remaining $64 \%$ had at least one student with SEN in their class, and the student(s) required a high level of support.

Among the 10 items, the following were below the item mean, meaning that the science teachers found it relatively easier to agree with these items:

During my science lessons,

B1: I actively engage students with SEN

B3: I helped students with SEN improve their academic results

B10: I had rapport with students with SEN

B2: I helped students with SEN understand new concepts

B7: I was patient in teaching students with SEN

B9*: I did not avoid making eye contact with students with SEN (“*” reverse coded items prior to Rasch analysis)

The science teachers reported helping these students to improve academically and understand new science concepts. They actively engaged students, developed rapport with them, were patient, and did not avoid making eye contact with them. It was interesting to note that these items in Construct B described what they did and their relationships with students. All these items were more easily agreed with by the science teachers in comparison to items $\mathrm{B}_{4}, \mathrm{~B}_{5}, \mathrm{~B} 6$ *, and $\mathrm{B}^{*}$ that were related to their self-competency views and emotions. One possible interpretation was that while they knew what they were doing $(\mathrm{B} 1$, $\mathrm{B}_{2}, \mathrm{~B}_{3}, \mathrm{~B}_{7}, \mathrm{~B}_{9}$ * and $\mathrm{B} 10$ ), they were not certain if they had done it correctly or did not know if what they had done was useful to the students with SEN. The latter was possibly related to the lack of training they had in the education of students with SEN (Avramidis \& Kalyva, 2007). Table 2 below shows their response to an item. 
TABLE 2 Item about the science teachers' training in the education of students with SEN

\begin{tabular}{|c|c|c|c|c|}
\hline Survey item & None & 1-10 hours & 11-40 hours & $\begin{array}{l}\text { More than } \\
40 \text { hours }\end{array}$ \\
\hline $\begin{array}{l}\text { How much training have } \\
\text { you had in the education } \\
\text { of students with SEN? } \\
(N=108)\end{array}$ & $\begin{array}{l}15 \cdot 7 \% \\
(n=17)\end{array}$ & $\begin{array}{l}35 \cdot 3 \% \\
(\mathrm{n}=38)\end{array}$ & $\begin{array}{l}30.4 \% \\
(n=33)\end{array}$ & $\begin{array}{l}18.6 \% \\
(n=20)\end{array}$ \\
\hline
\end{tabular}

\subsection{Construct C: Science Teaching Strategies in Inclusive Classrooms}

Construct $\mathrm{C}$ comprised items related to a range of evidence-based teaching strategies that worked in inclusive classrooms (Mitchell \& Sutherland, 2020). Figure 4 below shows the Wright map of Construct C. The item mean ("M" on the right side of the ruler) was about one logit lower than the person mean ("M" on the left side of the ruler). This meant that in general, it was easier for the teachers to agree with most of the items in this construct. For example, Item C14, "I planned specific seating arrangements for them," was relatively the easiest item for the teachers to agree with. Only one of the science teachers

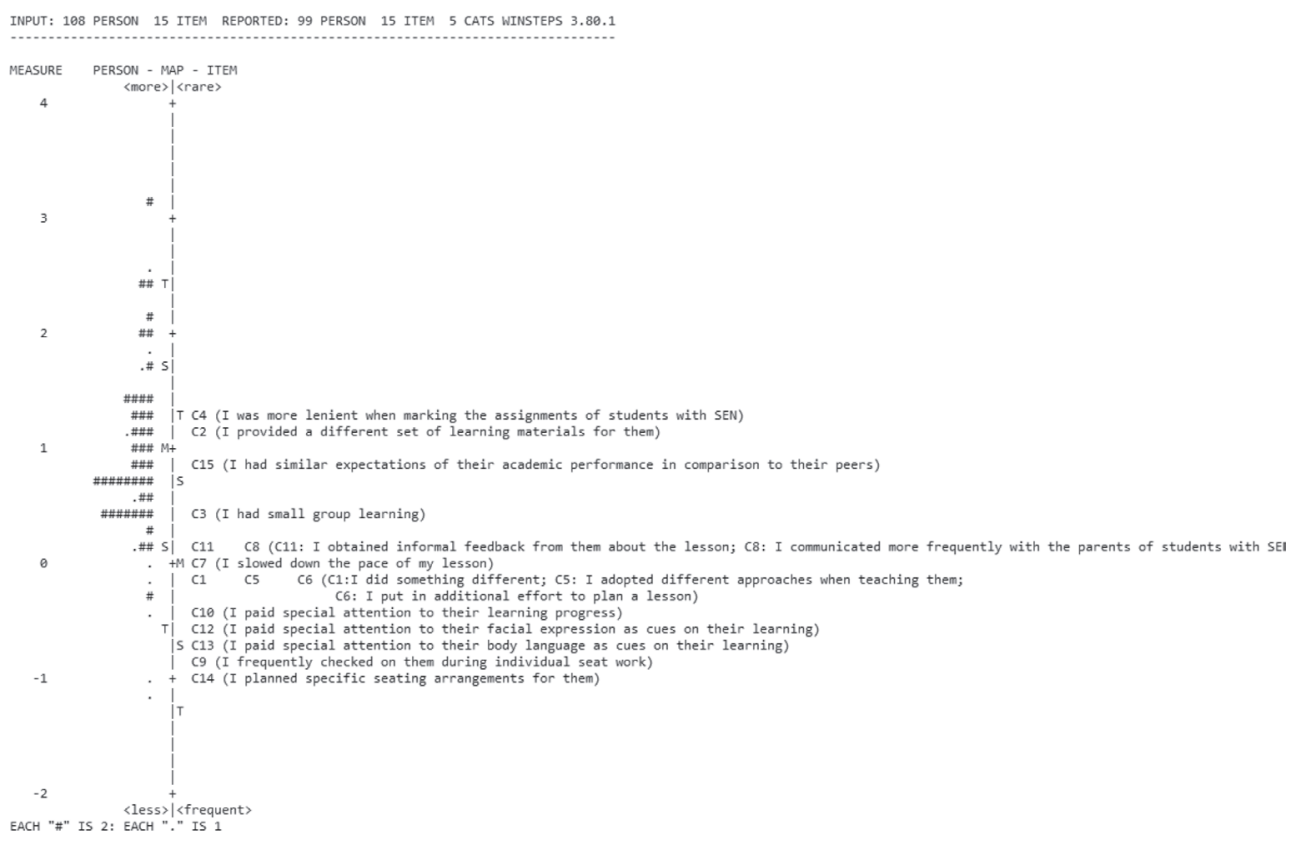

FIGURE 4 Wright map for 'Construct C: Science Teaching Strategies in Inclusive Classrooms' 
would likely disagree with this item. In what follows, I discuss these views in greater detail.

Among the 15 items, the following were on the item mean and above, meaning that the science teachers found it relatively harder to agree with these items:

In my science classroom with students with SEN,

C4: I was more lenient when marking the assignments of students with SEN

C2: I provided a different set of learning materials for them

C15: I had similar expectations of their academic performance in comparison to their peers

$\mathrm{C}_{3}$ : I had small group learning

C11: I obtained informal feedback form them about the lesson

C8: I communicated more frequently with the parents of students with SEN

$\mathrm{C}_{7}$ : I slowed down the pace of my lessons

It was interesting to note that it was relatively harder for the science teachers to agree on the items related to making accommodations for students with SEN. Even though the science teachers were agreeable on most items, $68 \%$ of the science teachers reported that the most difficult item for them to agree with was $\mathrm{C}_{4}$, "I was more lenient when marking the assignments of students with SEN." This could be explained by Item C15, "I had similar expectations of their academic performance in comparison to their peers," which had about half of the science teachers who would most likely agree with the item. This suggests that they would not practice leniency in marking due to having similar expectations on all students' performances. Items related to making other accommodations and modifications such as providing a different set of learning materials $\left(\mathrm{C}_{2}\right)$, arranging for small-group learning $\left(\mathrm{C}_{3}\right)$, and slowing down the pace of lessons $\left(\mathrm{C}_{7}\right)$, were also relatively harder for the science teachers to agree with. The Items C11, "I obtained informal feedback from them about the lesson," and C8, "I communicated more frequently with the parents of students with SEN," seemed to suggest the lack of two-way interactions between the science teachers with the students and students' parents.

Among the 15 items, the following were below the item mean, meaning that the science teachers found it relatively easier to agree with these items:

In my science classroom with students with SEN,

$\mathrm{Cr}^{*}$ : I did something different

$\mathrm{C}_{5}$ : I adopted different approaches when teaching them 
C6: I put in additional effort to plan a lesson

C1o: I paid special attention to their learning progress

C12: I paid special attention to their facial expression as cues about their learning

C13: I paid special attention to their body language as cues about their learning

C9: I frequently checked on them during individual seatwork

C14: I planned specific seating arrangements for them (“*” reverse coded items prior to Rasch analysis)

While the science teachers reportedly found it difficult to agree with the earlier set of items, this set of findings showed that they generally did make some accommodations and modifications to their science teaching for the students with SEN. For example, they adopted different teaching approaches $\left(\mathrm{C}_{5}\right)$, put in additional effort in lesson planning (C6), and planned specific seating arrangements for them (C14). The science teachers also reported paying special attention to the learning progress of the students with SEN (C1O). This was consistent with Item $\mathrm{C} 9$ in this group as well. Some of the specific things they did were to pay special attention to their facial expression and body language, which they used as cues on the students' learning. Such nonverbal communications were important in teaching (White \& Gardner, 2012).

In sum, the findings from the analysis of Construct $\mathrm{C}$ illuminated the kind of accommodations and modifications that the science teachers were more or less willing to afford to students with SEN. Much more is known on how to significantly improve the science achievements of students with SEN (Villaneuva, Taylor, Therrien, \& Hand, 2012). Such efforts could be successful if science teachers modify their instructional strategies to accommodate their instruction and assessment practices students with SEN (Parmar, Deluca, \& Janczak, 1994; Scruggs \& Mastropieri, 1995).

\section{$7 \quad$ Implications}

This study has implications for general and science educators in the academic/ research community and teacher education. For the academic community, it contributes to the literature by broadening and deepening the academic dialogue about inclusive science education, and providing a methodologically sound instrument (online survey) that, when coupled with inference statistics, empowers educators to draw useful inferences to inform interventions. For science teacher educators in Singapore, it informs us about the type of support 
that teachers need, and these can be incorporated into the design of in-service and pre-service courses. If the findings from the constructs resonate with science teacher educators in contexts outside of Singapore, the suggestions may also indicate similar types of science teacher education courses that may be offered elsewhere. Accordingly, I will elaborate on two specific areas of implications for the science education academic community and science teacher educators.

First, this study contributes to the existing literature on science education, which has a paucity of research about inclusive education in comparison to other topics such as the nature of science, students' alternative conceptions, and science inquiry. A literature scan of empirical studies in special needs science education revealed that the majority of the studies focused on students with special needs, while there were fewer studies that reported about science teachers. Additionally, a scan of the related general education literature revealed more studies about pre-service teachers' self-efficacy views (e.g., Loreman, Sharma, \& Forlin, 2013) than in-service teachers' self-efficacy views on inclusive teaching. There could be two possible reasons for this. First, there might be an assumption that pre-service teachers had greater concerns about inclusive teaching, so their knowledge needed to be diagnosed and established. Second, teacher education courses might be designed to address their needs while they were undergoing teaching training. Hence, interventions were more easily designed and implemented for them. Therefore, this study contributes to the literature by adding to the number of inclusive science teacher studies.

Additionally, the study offers comprehensive and in-depth insights about in-service science teachers' personal and external views and actions in inclusive science teaching. Construct A measured the science teachers' constructed views about their students, and such views were about others (external). On the other hand, Construct B measured the science teachers' personally constructed views of themselves (internal). Construct $\mathrm{C}$ measured their actionable behaviors as a result of their externally and internally constructed perceptions about inclusive science teaching. Together, these three constructs form a comprehensive combination of ideas to examine what science teachers think and $d o$. Deeper understandings of each construct were obtained by analyzing the data using inference statistics. In this case, Rasch analysis afforded useful inferences. For example, in the interpretations of Construct B, nuances between items revealed the science teachers' inner tensions. The science teachers found it relatively easier to agree with items related to the actions they undertook. Additionally, the nuances in the science teachers' self-efficacy views were new insights added to the literature. Notably, the online survey instrument used to collect the data in this study had been validated and hence, 
may be adopted in other research. To date, the survey had been translated in Mandarin and Korean for an international study. The findings of the study will be reported elsewhere.

Second, the findings of this study have implications for science teacher educators, particularly in the design of courses for supporting inclusive science teaching. It had been well established in the literature that continuing teacher education has been important for promoting positive teachers' attitudes toward inclusive teaching (e.g., Avramidis \& Kalyva, 2007; Kurniawati, de Boer, Minnaert, \& Mangunsong, 2016; Rojewski \& Pollard, 1993). The study on Greek general education primary school teachers by Avramidis and Kalyva (2007) revealed that teachers with further training in SEN and inclusion matters hold significantly more positive attitudes than those with little or no training concerning inclusion. It is interesting to note from this study that while the science teachers felt that more school support was needed, they were more neutral in their views about undergoing teacher professional development in inclusive science teaching. Perhaps the science teachers had responded to the latter item in thinking that there were additional areas of teacher professional development on top of the science-related professional development. However, the science education literature has informed us that inquiry-based teaching, espoused in science education for decades, could foster inclusive education for students (Abels, 2014). In particular, systematic and self-directed inquiry modes of instruction have been found to be effective approaches for teaching science to students with developmental disabilities, and these students were likely to be able to carry out science inquiry work with some independence (Apanasionok, Hastings, Grindle, Watkins, \& Paris, 2018; Coberm, Schuster, Adams, Applegate, Skjold, Undreiu, et al., 2010). Since science inquiry is core in most - if not all - science teacher education programs, it will make sense to build on existing efforts to promote science inquiry teaching to address the needs of students with SEN. This will contribute to efforts in empowering teachers with the knowledge and tools to teach well.

This article reported on the findings of an online teacher survey administered to Singapore primary science teachers as part of a first local study to examine science teachers and science teaching in inclusive science classrooms. Rasch analysis of the survey responses showed that it was generally difficult for the science teachers to agree with the items under Construct A: science 
teachers' views about students with SEN. However, it was generally easy for the science teachers to agree with the items under Construct B: science teachers' self-efficacy views in teaching students with SEN and Construct C: science teaching strategies in inclusive classrooms. In unpacking the items within in construct, deeper insights were gained. The key insights drawn about the science teachers include that (a) they generally had positive views about their students with SEN; (b) while they were stressed and felt inadequate teaching alone in inclusive classrooms, other survey items showed that they wanted more school support but did not favor undergoing teacher professional development in inclusive teaching; and (c) they had made selected accommodations and modifications to their science teaching. This study has contributed to the literature by offering insights gleaned from a study with science teachers in an Asian context and adding to the vast, non-disciplinary specific SEN literature. Implications for science teacher educators designing professional development courses for science teachers that could address both pedagogical learning and differentiated instructions for students with SEN were discussed.

\section{Abbreviations}

$\begin{array}{ll}\text { ADHD } & \text { Attention Deficit Hyperactivity Disorder } \\ \text { AED } & \text { Allied Educator } \\ \text { LBS } & \text { Learning and Behavioral Support } \\ \text { MOE } & \text { Ministry of Education } \\ \text { NIE } & \text { National Institute of Education } \\ \text { QR } & \text { Quick Response } \\ \text { SEN } & \text { Special Education Needs } \\ \text { SFEd } & \text { SkillsFuture for Educators } \\ \text { SPED } & \text { Special Education }\end{array}$

\section{Funding}

This study was funded by Singapore Ministry of Education (MOE) under the Education Research Funding Program (OER 25/17 TTW) and administered by National Institute of Education (NIE), Nanyang Technological University (NTU), Singapore. Any opinions, findings, conclusions, and recommendations expressed in this material are those of the author(s) and do not necessarily reflect the views of the Singapore MOE and NIE. 


\section{Ethical Considerations}

Approval was obtained from the NTU Institutional Review Board (IRB-2018-O5O57) and MOE (EDUN N32-O7-OO5) prior to the research data collection.

\section{About the Author}

Tang Wee Teo $(\mathrm{PhD})$ is an Associate Professor at the National Institute of Education, Nanyang Technological University, Singapore. Her research work focuses on equity issues in science and STEM education.

\section{References}

Abels, S. (2014). Inquiry-based science education and special needs - Teachers' reflections on an inclusive setting. Sisyphus, 2(2), 124-154. doi:10.25749/sis.4069.

Ajzen, I. (1991). The theory of planned behavior. Organizational Behavior and Human Decision Processes, 5o(2), 179-211. doi:10.1016/o749-5978(91)9oo2o-T.

Apanasionok, M. M., Hastings, R. P., Grindle, C. F., Watkins, R. C., \& Paris, A. (2019). Teaching science skills and knowledge to students with developmental disabilities: A systematic review. Journal of Research in Science Teaching, 56(7), 847-880. doi:10.1002/tea.21531.

Avramidis, E., \& Kalyva, E. (2007). The influence of teaching experience and professional development on Greek teachers' attitudes towards inclusion. European Journal of Special Needs Education, 22(4), 367-389. doi:10.1080/08856250701649989.

Azman, D. S. B., \& Teo, T. W. (2019, September). A critical review of studies on special needs in science education. Paper presented at British Education Research Association Conference, Manchester, United Kingdom.

Bond, T., \& Fox, C. M. (2015). Applying the Rasch model: Fundamental measurement in the human sciences (Third ed.). New York, NY: Routledge.

Boone, W. J. (2016). Rach analysis for instrument development: Why, when, and how? CBE Life Science Education, 15(4). doi:10.1187/cbe.16-04-0148.

Brady, K., \& Woolfson, L. (2008). What teacher factors influence their attributions for children's difficulties in learning? British Journal of Educational Psychology, 78(4), 527-544. doi:10.1348/000709907 Х268570.

Carter, E. W., \& Kennedy, C. H. (2006). Promoting access to the general curriculum using peer support strategies. Research and Practice for Persons with Severe Disabilities, 31(4), 284-292. doi:10.1177/154079690603100402. 
Chi, M. T. H., Slotta, J. D., \& De Leeuw, N. (1994). From things to processes: A theory of conceptual change for learning science concepts. Learning and Instruction, 4(1), 27-43. doi:10.1016/o959-4752(94)9oo17-5.

Cobern, W. W., Schuster, D., Adams, B., Applegate, B., Skjold, B., Undreiu, A., Loving, C. C., \& Gobert, J. D. (2010). Experimental comparison of inquiry and direct instruction in science. Research in Science \& Technological Education, 28(1), 81-96. doi:10.108o/o2635140903513599.

Creswell, J. W. (2008). Educational research: Planning, conducting, and evaluating quantitative and qualitative research (Third ed.). Upper Saddle River, NJ: Pearson Education.

Davis, P., \& Florian, L. (2004). Teaching strategies and approaches for pupils with special educational needs: A scoping study. Retrieved on June 17, 2020 from https://dera.ioe .ac.uk/6o59/1/RR516.pdf.

Disabled People's Association. (2016). Achieving inclusion in education: Understanding the needs of students with disabilities. Retrieved from http://www.dpa.org.sg/wp -content/uploads/2016/o7/Incusion-in-Education.pdf.

Ellis, E. S. (1993). Integrative strategy instruction: A potential model for teaching content area subjects to adolescents with learning disabilities. Journal of Learning Disabilities, 26(6), 358-383. doi:10.1177/oo22219493026oo6o2.

Fishbein, M. \& Ajzen, I. (1975). Belief, attitude, intention and behavior: An introduction to theory and research. Reading, MA: Addison-Wesley.

Gillies, R. M., \& Ashman, A. F. (2000). The effects of cooperative learning on students with learning difficulties in the lower elementary school. The Journal of Special Education, 34(1), 19-27. doi:10.1177/002246690003400102.

Herrick, M. J. (1973). Disabled or Disadvantaged: What's the Difference? The Journal of Special Education. 7(4), 381-386. doi:10.1177/002246697300700406.

Hodson, D. (2014). Learning science, learning about science, doing science: Different goals demand different learning methods. International Journal of Science Education, $36(15)$, 2534-2553. DOI: 10.1080/o950o693.2014.899722.

Jarvis, T., \& Pell, A. (2004). Primary teachers' changing attitudes and cognition during a two-year science in-service program and their effect on pupils. International Journal of Science Education, 26(14), 1787-1811. doi:10.1080/o950069042000243763.

Jimenez, B. A., Browder, D. M., Spooner, F., \& Dibiase, W. (2012). Inclusive inquiry science using peer-mediated embedded instruction for students with moderate intellectual disability. Exceptional Children, 78(3), 301-317. doi:10.1177/001440291207800303.

Kahn, S., \& Lewis, A. R. (2014). Survey on teaching science to K-12 students with disabilities: Teacher preparedness and attitudes. Journal of Science Teacher Education, 25(8), 885-910. doi:10.1007/s10972-014-9406-z.

Kurniawati, F., de Boer, A. A., Minnaert, A. E. M. G., \& Mangunsong, F. (2017). Evaluating the effect of a teacher training program on the primary teachers' attitudes, 
knowledge and teaching strategies regarding special educational needs. Educational Psychology, 37(3), 287-297. doi:10.1080/01443410.2016.1176125.

Loreman, T., Sharma, U., \& Forlin, C. (2013). Do pre-service teachers feel ready to teach in inclusive classrooms? A four country study of teaching self-efficacy. Australian Journal of Teacher Education, 38(1), 27-44. doi:10.14221/ajte.2013v38n1.10.

Malinen, O., Savolainen, H., Engelbrecht, P., Xu, J., Nel, M., Nel, N., \& Tlale, D. (2013). Exploring teacher self-efficacy for inclusive practices in three diverse countries. Teaching and Teacher Education, 33, 34-44. doi:10.1016/j.tate.2013.02.004.

Mastropieri, M. A., \& Scruggs, T. E. (1992). Science for students with disabilities. Review of Educational Research, 62(4), 377-411. doi:10.3102/00346543062004377.

Mastropieri, M. A., Scruggs, T. E., Norland, J. J., Berkeley, S., McDuffie, K., Tornquist, E. H., \& Connors, N. (2006). Differentiated curriculum enhancement in inclusive middle school science: Effects on classroom and high-stakes tests. Journal of Special Education, 40(3), 130-137. doi: 10.1177/00224669o60400030101.

Ministry of Education. (2020). SkillsFuture for educators. Retrieved June 17, 2020 from https://www.moe.gov.sg/microsites/cos2020/skillfuture-for-educators.html.

Ministry of Social and Family Development (2016). Third Enabling Masterplan 20172021: Caring Nation, Inclusive Society. Retrieved from https://www.enablingguide .sg/docs/default-source/publications/enabling-masterplan-3-(revised-13-jan-2017). pdf?sfvrsn=bo5da8ae_2.

Mitchell, D. R., \& Brown, R. I. (Eds.) (1991). Early intervention studies for young children with special needs. Springer.

Mitchell, D., \& Sutherland, D. (2020). What really works in special and inclusive education: Using evidence-based teaching strategies (Third ed.). London, UK: Taylor \& Francis.

National Council of Social Service (2020). Adults with disabilities. Retrieved June 17, 2020 from https://www.ncss.gov.sg/GatewayPages/Social-Services/Adult-with-Disabilities.

National Institute of Education. (2020). Professional learning catalogue: January to June 2020. Retrieved from https://www.nie.edu.sg/docs/default-source/gpl/pd -catalogue-(jan-jun-2020)_fa(web).PDF.

Norman, K., Caseau, D., \& Stefanich, G. P. (1998). Teaching students with disabilities in inclusive science classrooms: Survey results. Science Education, 82(2), 127-146. doi:10.1002/(SICI)1098-237X(199804)82:2<127::AID-SCE1>3.o.CO;2-G.

OECD. (2007). Students with disabilities, learning difficulties and disadvantages: Policies, statistics and indicators. Paris: OECD Publishing. Retrieved June 17, 2020 from https://doi.org/10.1787/9789264027619-en.

OECD. (2008). OECD policy brief. Paris: Secretary-General of the OECD. Retrieved June 17, 2020 from https://www.oecd.org/education/school/39989494.pdf.

Ong, Y. K. (2020, March 9). MOE FY2020 Committee of Supply Debate Response by Minister for Education Ong Ye Kung [Transcript] Retrieved from https://www.moe 
.gov.sg/news/speeches/moe-fy2020-committee-of-supply-debate-response-by -minister-for-education-ong-ye-kung.

PACER Center. (2018). School accommodation ideas for students who receive Section 504 or special education services. Retrieved from https://www.pacer.org/parent/php/ PHP-c267.pdf.

Palincsar, A. S., Magnusson, S. J., Collins, K. M., \& Cutter, J. (2001). Making science accessible to all: Results of a design experiment in inclusive classrooms. Learning Disability Quarterly, 24(1), 15-32. doi:10.2307/1511293.

Parmar, R. S., Deluca, C. B., \& Janczak, T. M. (1994). Investigations into the relationship between science and language abilities of students with mild disabilities. Remedial and Special Education, 15(2), 117-126. doi:10.1177/074193259401500207.

Rojewski, J. W., \& Pollard, R. R. (1993). A multivariate analysis of perceptions held by secondary academic teachers toward students with special needs. Teacher Education and Special Education, 16(4), 330-341.

Salkind, N. J. (2010a). Encyclopedia of research design (Vols. 1-o). Thousand Oaks, CA: SAGE Publications, Inc. doi:10.4135/9781412961288.

Salkind, N. J. (2010b). Encyclopedia of research design (Vols. 1-o). Thousand Oaks, CA: SAGE Publications, Inc. doi:10.4135/9781412961288.

Scruggs, T. E., \& Mastropieri, M. A. (1991). Classroom applications of mnemonic instruction: Acquisition, maintenance, and generalization. Exceptional Children, 58(3), 219-229. doi:10.1177/o01440299105800305.

Scruggs, T. E., \& Mastropieri, M. A. (1995). Science and students with mental retardation: An analysis of curriculum features and learner characteristics. Science Education, 79(3), 251-271. doi:10.1002/sce.3730790303.

Scruggs, T. E., \& Mastropieri, M. A. (2007). Science learning in special education: The case for constructed versus instructed learning. Exceptionality, 15(2), 57-74. doi:10.1080/09362830701294144.

Spektor-Levy, O., \& Yifrach, M. (2019). If science teachers are positively inclined toward inclusive education, why is it so difficult? Research in Science Education, 49(3), 737766. doi:10.1007/s11165-017-9636-o.

Steele, M. M. (2004). Teaching science to students with learning problems in the elementary classroom. Preventing School Failure: Alternative Education for Children and Youth, 49(1), 19-21. doi:10.3200/PSFL.49.1.19-21.

Teo, T. W. (2015). Inside versus outside the science classroom: Examining the positionality of two female science teachers at the boundaries of science education. Cultural Studies of Science Education, 10(2), 381-402. DOI 10.1007/s11422-014-9581-4.

Teo, T. W. \& Goh, W. P. J. (2019). Assessing Lower Track Students' Learning in Science Inference Skills in Singapore. Asia-Pacific Science Education, 5, 1-19. doi:10.1186/ s41029-019-0o33-z. 
Teo, T. W., Goh, W. P. J., Khin, M. A., \& Yeo, L. W. (2018). Rethinking teaching and learning of science inference competencies of lower track students in Singapore: A Rasch investigation. Asia Pacific Journal of Education, 12(3), 279-302. doi:10.108o/o218879 1.2018.1476320.

Urton, K., \& Wilbert, J., \& Hennemann, T. (2014). Attitudes towards inclusion and selfefficacy of principals and teachers in German primary schools. Learning Disabilities: A Contemporary Journal, 12(2), 151-168.

Van Reusen, A. K., Shoho, A. R., \& Barker, K. S. (2001). High school teacher attitudes toward inclusion. The High School Journal, 84(2), 7-20.

Villanueva, M. G., Taylor, J., Therrien, W., \& Hand, B. (2012). Science education for students with special needs. Studies in Science Education, 48(2), 187-215. doi:10.1080/ 14703297.2012.737117.

Weinburgh, M. (2007). The effect of Tenebrio obscurus on elementary pre-service teachers' content knowledge, attitudes, and self-efficacy. Journal of Science Teacher Education, 18(6), 801-815. doi:10.1007/s10972-0o7-9073-4.

White, J., \& Gardner, J. (2012). The classroom $x$-factor: The power of body language and non-verbal communication in teaching. London, UK: Routledge.

Wigle, S. E., \& Wilcox, D. J. (1996). Inclusion: Criteria for the preparation of education personnel. Remedial and Special Education, 17(5), 323-328. doi:10.1177/o741932 59601700508 .

Wright, B. D. (1993). Logits? Rasch Measurement Transactions, 7(2), 288. Retrieved from https://www.rasch.org/rmt/rmt72e.htm.

Wright, B. D., \& Linacre, J. M. (1994). Reasonable mean-square fit values. Rasch Measurement Transactions, 8(3), 37o. Retrieved from https://www.rasch.org/rmt/ rmt83b.htm.

Wright, B. D., \& Masters, G. N. (1982). Rating scale analysis. Chicago, IL: MESA Press.

Wright, B. D., \& Stone, M. H. (1979). Best test design. Chicago, IL: MESA Press.

Zee, M., \& Koomen, H. M. Y. (2016). Teacher self-efficacy and its effects on classroom processes, student academic adjustment, and teacher well-being: A synthesis of 40 years of research. Review of Educational Research, 86(4), 981-1015. doi:10.3102/0034654315626801.

\section{Appendix A}

\section{Science Teacher Survey Instrument}

Q1. What is your gender?
O Male
O Female 
Q2. What is your age? (Based on year of birth)
O 25 years or below
○ 26-35 years
O 36-45 years
O 46-55 years
O 56 years or above

Q3. What is the highest level of education that you have completed?
O GCE "A" Level
O Diploma
O Advanced Diploma
O Bachelor Degree
O Postgraduate Degree (Master's, $\mathrm{PhD}$ )

Q4. How many years of science teaching experience do you have? (Exclude pre-service teacher preparation)
$\bigcirc \quad$ Less than 3 years
O 3-5 years
O 6-10 years
O More than 10 years

For this survey, the phrase "special education needs" (SEN) only includes autism spectrum disorders, ADHD, intellectual disabilities, and learning disabilities (e.g., dyslexia). Q5. How much interaction have you had with students with SEN outside the classroom?

O None

O Some

O A lot

Q6. How much training have you had in the education of students with SEN?
O None
O $1-10$ hours
O 11-40 hours
O More than 40 hours

Q7. What is your level of knowledge of local policies pertaining to students with SEN? (Slide the pointer)

Level () \begin{tabular}{lllllll} 
& Low & & \multicolumn{3}{c}{ High } \\
& 0 & 1 & 2 & 3 & 4 & 5 \\
& & & & & &
\end{tabular}


Q8. What is your level of confidence in teaching/supporting students with SEN? (Slide the pointer)

Level ()

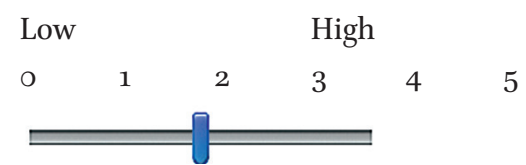

Q9. Which of the following best describes your experience teaching/supporting students with SEN?

O I have had at least one student with SEN in my class, but the student(s) did not require a level of support.

O I have had at least one student with SEN in my class, and the student(s) required a high level of support.

\section{Views about Students with SEN}

Q10. Using the scale below, please choose a response to each statement that best describes your views about students with SEN in science lessons.

In comparison to their peers, students with SEN

\begin{tabular}{llllll}
\hline & $\begin{array}{l}\text { Strongly } \\
\text { agree }\end{array}$ & $\begin{array}{l}\text { Somewhat } \\
\text { agree }\end{array}$ & $\begin{array}{l}\text { Neither } \\
\text { agree nor } \\
\text { disagree }\end{array}$ & $\begin{array}{l}\text { Somewhat } \\
\text { disagree }\end{array}$ & $\begin{array}{l}\text { Strongly } \\
\text { disagree }\end{array}$ \\
\hline $\begin{array}{l}\text { score equally well } \\
\text { in assessments }\end{array}$ & 0 & 0 & 0 & 0 & 0 \\
$\begin{array}{l}\text { experience more } \\
\text { difficulty learning } \\
\text { science }\end{array}$ & 0 & 0 & 0 & 0 & 0 \\
$\begin{array}{l}\text { experience more } \\
\text { difficulty completing } \\
\text { science hands-on } \\
\text { activity }\end{array}$ & 0 & 0 & 0 & 0 & 0 \\
\end{tabular}


(cont.)

Strongly Somewhat Neither Somewhat Strongly

agree agree agree nor disagree disagree

disagree

need more time to $\quad 0 \quad 0 \quad 0000$

learn the same

science concept

need more time to

O

O

O

O

O

develop science

process skills

require a higher level

$\bigcirc$

O

O

O

O

of peer support

face more challenges

$\bigcirc$

O

O

O

$\bigcirc$

when collaborating in

group work

prefer one-to-one

O

O

O

O

O

instruction

are not as proactive in

O

O

O

O

O

science lessons

get frustrated more

○

O

O

O

O

easily

are sensitive to changes $\bigcirc$

$\bigcirc$

O

O

O

in the environment

(e.g., light, sound, and temperature) 


\section{Self-Efficacy Views}

Q11. Using the scale below, please choose a response to each statement that best describes your self-efficacy about teaching students with SEN in science lessons.

During my science lessons,

\begin{tabular}{|c|c|c|c|c|c|}
\hline & $\begin{array}{l}\text { Strongly } \\
\text { agree }\end{array}$ & $\begin{array}{l}\text { Somewhat } \\
\text { agree }\end{array}$ & $\begin{array}{l}\text { Neither } \\
\text { agree nor } \\
\text { disagree }\end{array}$ & $\begin{array}{l}\text { Somewhat } \\
\text { disagree }\end{array}$ & $\begin{array}{l}\text { Strongly } \\
\text { disagree }\end{array}$ \\
\hline $\begin{array}{l}\text { I actively engaged } \\
\text { students with SEN }\end{array}$ & 0 & 0 & 0 & 0 & 0 \\
\hline $\begin{array}{l}\text { I helped students } \\
\text { with SEN understand } \\
\text { new concepts }\end{array}$ & 0 & 0 & 0 & 0 & 0 \\
\hline $\begin{array}{l}\text { I helped students with } \\
\text { SEN improve their } \\
\text { academic results }\end{array}$ & 0 & 0 & 0 & O & 0 \\
\hline $\begin{array}{l}\text { I was able to accurately } \\
\text { identify the learning } \\
\text { needs of students } \\
\text { with SEN }\end{array}$ & O & 0 & O & O & O \\
\hline $\begin{array}{l}\text { I knew how to cater } \\
\text { to the learning needs } \\
\text { of students with SEN }\end{array}$ & 0 & 0 & 0 & O & O \\
\hline $\begin{array}{l}\text { I felt inadequate } \\
\text { teaching a class with } \\
\text { students with SEN all } \\
\text { by myself }\end{array}$ & O & 0 & O & O & O \\
\hline $\begin{array}{l}\text { I was patient in } \\
\text { teaching students } \\
\text { with SEN }\end{array}$ & 0 & 0 & 0 & 0 & 0 \\
\hline
\end{tabular}


(cont.)

$\begin{array}{llll}\text { Strongly } & \begin{array}{l}\text { Somewhat } \\ \text { agree }\end{array} & \begin{array}{l}\text { Neither } \\ \text { agree }\end{array} & \begin{array}{l}\text { Somewhat Strongly } \\ \text { agree nor } \\ \text { disagree }\end{array}\end{array}$

it was very stressful to

teach a class with

students with SEN

I avoided making eye

O

O

O

O

O

contact with students

with SEN

I had rapport with my

$\bigcirc$

O

O

O

O

students with SEN

Q12. I was supported by my school to teach students with SEN
O Strongly agree
O Somewhat agree
O Neither agree nor disagree
O Somewhat disagree
O Strongly disagree

Q13. I needed more support from my school in order to teach students with SEN
O Strongly agree
O Somewhat agree
O Neither agree nor disagree
O Somewhat disagree
O Strongly disagree

Q14. I am well prepared to teach students with SEN since I was a pre-service teacher
O Strongly agree
O Somewhat agree
O Neither agree nor disagree
O Somewhat disagree
O Strongly disagree

Q15. I need to undergo more professional development in the science teaching of students with SEN
O Strongly agree
O Somewhat agree 

$\mathrm{O}$ Neither agree nor disagree
O Somewhat disagree
O Strongly disagree

\section{Science Teaching Practices}

Q16. Using the scale below, please choose a response to each statement that best describes the teaching practices in science classrooms with students with SEN.

In my science classroom with students with SEN,

$\begin{array}{lllll}\text { Strongly } & \begin{array}{l}\text { Somewhat } \\ \text { agree }\end{array} & \begin{array}{l}\text { Neither } \\ \text { agree }\end{array} & \begin{array}{l}\text { Somewhat } \\ \text { agree nor } \\ \text { disagree }\end{array} & \begin{array}{l}\text { Strongly } \\ \text { disagree }\end{array} \\ & & & \end{array}$

$\begin{array}{lllll}\text { I did not have to do } \quad 0 & 0 & 0 & 0\end{array}$

anything different

$\begin{array}{lllll}\text { I provided a different } & O & O & O & 0\end{array}$

materials for them

$\begin{array}{llllll}\text { I had small-group } & 0 & 0 & 0 & 0 & 0\end{array}$

learning
I was more lenient
when marking the
assignments of
students with SEN

O

$\bigcirc$

O

$\mathrm{O}$

O

I adopted different

O

O

O

O

O

approaches when

teaching them

I put in additional

O

O

$\bigcirc$

O

O

effort to plan a lesson

I slowed down the

O

O

O

O

O

pace of my lesson 
(cont.)

$\begin{array}{lllll}\begin{array}{l}\text { Strongly } \\ \text { agree }\end{array} & \begin{array}{l}\text { Somewhat } \\ \text { agree }\end{array} & \begin{array}{l}\text { Neither } \\ \text { agree nor } \\ \text { disagree }\end{array} & \begin{array}{l}\text { Somewhat } \\ \text { disagree }\end{array} & \begin{array}{l}\text { Strongly } \\ \text { disagree }\end{array} \\ & & & \end{array}$

I communicated more $\mathrm{O}$

$\mathrm{O}$

O

O

frequently with the

parents of students

with SEN

I frequently checked

O

$\bigcirc$

$\mathrm{O}$

O

O

on them during

individual seat work

I paid special

O

O

O

O

O

attention to their

learning progress

I obtained informal

O

O

O

O

O

feedback from them

about the lesson

I paid special

O

O

$\bigcirc$

O

O

attention to their

facial expression

as cues about their

learning

I paid special

O

O

○

O

$\bigcirc$

attention to their

body language as

cues on their learning

I planned specific

O

$\mathrm{O}$

O

O seating arrangements

for them 
(cont.)

$\begin{array}{lllll}\begin{array}{l}\text { Strongly } \\ \text { agree }\end{array} & \begin{array}{l}\text { Somewhat } \\ \text { agree }\end{array} & \begin{array}{l}\text { Neither } \\ \text { agree nor } \\ \text { disagree }\end{array} & \begin{array}{l}\text { Somewhat } \\ \text { disagree }\end{array} & \begin{array}{l}\text { Strongly } \\ \text { disagree }\end{array} \\ & & & \end{array}$

I had similar

O

$\bigcirc$

O

O

expectations of their

academic performance

in comparison to their

peers

\section{Appendix B}

\section{Person and Item Separation Reliabilities}

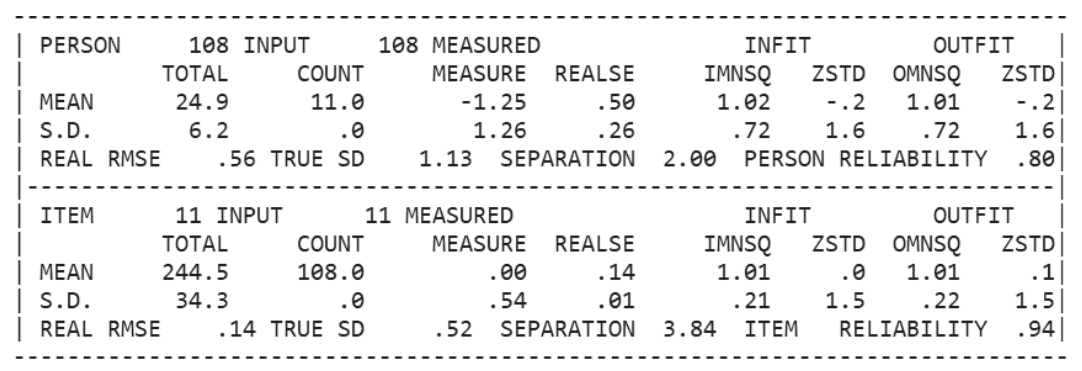

FIGURE B1 Person and item separation reliabilities for Construct A

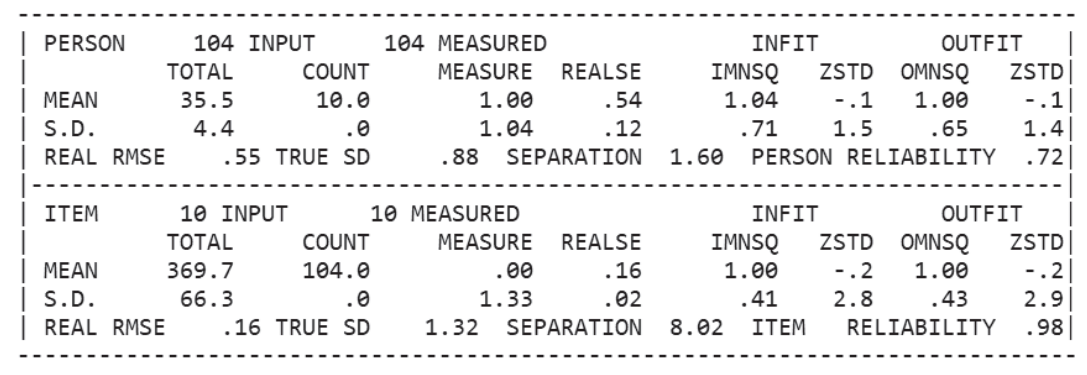

FIGURE B2 Person and item separation reliabilities for Construct B 


\begin{tabular}{|c|c|c|c|c|c|c|c|c|c|c|}
\hline \multirow[t]{2}{*}{ PERSON } & \multicolumn{2}{|c|}{108 INPUT } & \multicolumn{3}{|c|}{99 MEASURED } & \multicolumn{3}{|c|}{ INFIT } & \multicolumn{2}{|c|}{ OUTFIT } \\
\hline & TOTAL & COUNT & \multicolumn{2}{|c|}{ MEASURE } & REALSE & \multicolumn{2}{|c|}{ IMNSQ } & ZSTD & OMNSQ & ZSTD \\
\hline MEAN & 56.7 & 15.0 & & .95 & .40 & & 1.13 &.$\theta$ & 1.05 & -.1 \\
\hline S.D. & 6.7 &.$\theta$ & & .77 & .13 & & .80 & 1.8 & .74 & 1.7 \\
\hline REAL RMSE & $.42 \mathrm{~T}$ & TRUE SD & .64 & SEF & ARATION & 1.52 & PER & ON REL & IABILITY & .70 \\
\hline TTFM & $15 \mathrm{TNl}$ & & - MEASUR & & & & TNF & & (0) & \\
\hline & & & & & & & & & & \\
\hline & TOTAL & COUNT & MEAS & URE & REALSE & & MNSQ & ZSTD & OMNSQ & ZSTD \\
\hline MEAN & 374.3 & 99.0 & & .00 & .14 & & .98 & -.2 & 1.05 & .1 \\
\hline S.D. & 41.9 &.$\theta$ & & .65 & .02 & & .40 & 2.7 & .46 & 2.9 \\
\hline REAL RMSE & .14 & UE SD & .64 & SEF & ARATION & 4.44 & ITE & REL & IABILITY & .95 \\
\hline
\end{tabular}

FIGURE B3 Person and item separation reliabilities for Construct C 